\title{
Cropping Practices and Their Drivers in Various Cropping Systems in Peri-urban Areas of Ouagadougou, Burkina Faso
}

\author{
Delphine Bernadette Ouédraogo ${ }^{1,2}$, Delwendé Innocent Kiba ${ }^{1}$, Zacharia Gnankambary ${ }^{1}$, Sheick K. Sangaré2, \\ Diakouba Sirima $^{3}$, Hassan Bismarck Nacro ${ }^{2} \&$ Michel Papaoba Sedogo ${ }^{1}$ \\ ${ }^{1}$ Centre National de la Recherche Scientifique et Technologique, Institut de l'Environnement et de Recherches \\ Agricoles, Ouagadougou, Burkina Faso \\ ${ }^{2}$ Institut du Développement Rural, Université Nazi Boni, Bobo Dioulasso, Burkina Faso \\ ${ }^{3}$ Ministère de l'Environnement, de l'Economie Verte et du Changement Climatique, Burkina Faso \\ Correspondence: Delwendé Innocent Kiba, Centre National de la Recherche Scientifique et Technologique, \\ Institut de l'Environnement et de Recherches Agricoles, BP 476 Ouagadougou 01, Burkina Faso. Tel: \\ 226-7076-2747. E-mail: innokiba@yahoo.fr
}

Received: August 12, 2019

doi:10.5539/jas.v11n18p52

\author{
Accepted: September 29, 2019 \\ Online Published: November 15, 2019 \\ URL: https://doi.org/10.5539/jas.v11n18p52
}

\begin{abstract}
The advantages of urban and peri-urban agriculture in West African cities, namely its contribution to food production, income generation and resorbing unemployment are well reported. In the peri-urban areas, cropping systems and practices are various and may affect differently soil properties. Those systems and practices may be driven by farms socio-economic conditions. Here we conducted a study in 133 peri-urban farms located at the vicinity of the city of Ouagadougou. Farmers were questioned on their cropping practices and soil samples were taken and analyzed for their total organic $\mathrm{C}$, available $\mathrm{P}$ and $\mathrm{K}$ contents. Principal component analysis allowed to study the variability of the farms considering cropping systems, the cropping practices and the farms socio-economic conditions. We found that in the studied cropping systems up to $60 \%$ of the farms variability was explained. Monoculture led to low soil organic carbon while polyculture led to low soil available K. The studied socio-economic conditions of the farms explained up to $60 \%$ of the variability in cropping practices.
\end{abstract}

Keywords: cropping systems, cropping practices, soil properties, farms diversity, peri-urban agriculture

\section{Introduction}

Urban and peri-urban agriculture in West African cities is an important sector contributing to food production, income generation and resorbing unemployment (Mougeot, 2000; Drechsel \& Dongus, 2010). Orsini et al. (2013) estimated that about 100-200 millions of urban farmers worldwide contribute to food security by providing the city markets with fresh horticultural goods. Whereas in urban areas agriculture is characterized by vegetables and ornamental plants production, in peri-urban areas, it is dedicated to vegetables and cereals production with an emphasis on the cereal crops (Drechsel et al., 2006; Kiba et al., 2012a, 2012b; Ouédraogo et al., 2019).

The urban and peri-urban agriculture in West Africa was investigated in numerous studies on the biophysical (Lompo et al., 2012; Sangaré et al., 2012) and the socio-economic aspects (Dossa et al., 2011; Abdulkadir et al., 2012; Chagomoka et al., 2015) or both (Kiba et al., 2012a). It was well reported that the use of solid and liquid wastes from the cities in this type of agriculture leads to increased crop yields but also to increased risks of contamination of soils and crops by heavy metals (Kiba et al., 2012b). Problems related to environment pollution and public health due to high inputs of mineral fertilizers (Sangaré et al., 2012; Lompo et al., 2012) and the use of pesticides (Amoah et al., 2006; Naré et al., 2015) were reported. In a socio-economic point of view, it was established that land tenure insecurity and non-agricultural land demand are major constraints in urban and peri urban agriculture (Drechsel \& Dongus, 2010; Ouédraogo et al., 2019). Chagomoka et al. (2015) using a transect approach in Burkina Faso showed that urban and peri-urban agriculture contribute to household food and nutrition security.

In the peri-urban areas there is a diversity of vegetable and cereal crops and also a diversity of cropping systems and practices (Dossa et al., 2011). Dossa et al. (2011) identified four agricultural systems based on market orientation, the diversification of farms activities and farms ressources endowment. In our study, we considered 
cropping systems based on crop management as i) monoculture of a given vegetable or a cereal crop specie, ii) polyculture of various vegetable and/or cereal species and iii) application of both systems. Little researches in peri-urban agriculture were carried out considering such cropping systems in relation to the socio-economic conditions of the farmers whereas this may allow to better understand the farming decisions, the cropping practices and their further effects on soils.

The objective of our study is to understand the cropping practices of the peri-urban farmers so as to provide recommendations for an increased sustainability or the cropping systems. Here we hypothesized that in the peri-urban areas, i) the diversity of the farms can be explained by their cropping practices, ii) the cropping systems affect soil properties and iii) cropping practices are determined by farms socio-economic conditions.

\section{Material and Method}

\subsection{Study Site}

The study was conducted in the peri-urban areas of Ouagadougou city within a radius of $25 \mathrm{~km}$ in the locatities of Bigtogo, Kamboinsé, Pabré, Pendissi, Peodogo, Loumbila, Roumtenga, Sakoula, Soguedin and Yamba where cereal and/or vegetables crops are grown. Those localities are covered by the municipalities of Ouagadougou, Pabré and Loumbila. The climate in this area is Sudano-Sahelian (Fontès \& Guinko, 1995) with a long dry season from November to May and a short rainy season from June to October. The soils are mainly tropical ferruginous types based on a large mass of fissured granite (Pallo \& Thiombiano, 1989). These soils have generally low organic matter content $(<1 \%)$, low total and available nutrients and are vulnerable to erosion and runoff.

\subsection{Selection of Farmers and Survey}

We selected 133 farmers spread over the study site based on their willingness to participate to the study and the criteria of producing cereal and/vegetable crops. This sample size was about $10 \%$ of the total population. Those farmers were questioned individually on their socio-economic conditions such as their age, gender, farm age, farm surface, labor capacity, level of equipment, education level, occupancy status of land, membership of an organization. The importance of such socio-economic conditions on the farming decisions are highlighted in Ouédraogo et al. (2019). The cropping systems of each farmer were also identified based on three systems namely the monoculture of cereal or vegetable crops, polyculture or both. The farmers were also questioned about their cropping practices such as the rate of mineral and/or organic fertilization and the cropped surface and species.

\subsection{Soil Sampling and Chemical Analyses}

In each field, soil samples were taken from 5 incremental sampling points on $0-20 \mathrm{~cm}$ of depth and a composite sample was made from the 5 subsamples. The soil sampling concerned only 30 vegetable fields and 30 cereal fields spread over the study site. The soil samples were air dried, sieved at $0.5 \mathrm{~mm}$ for the determination of their organic carbon content and $2 \mathrm{~mm}$ for the determination of their available $\mathrm{P}$ and $\mathrm{K}$ contents. The organic carbon was measured according to Walkley-Black method (Walkley \& Black, 1934). Available P was extracted using the Bray I method (Bray \& Kurtz, 1945) and then measured by colorimetry with an auto analyzer Skalar SANplus Segmented flow analyzer, Model 4000-02, Holland. The available K was extracted using a solution of oxalic and hydrochloric acid and then measured with a flame photometer Jencons PFP 7, Jenway LTD, Felsted, England.

\subsection{Data Analysis}

The distribution of the rates of mineral and organic fertilizers were analyzed trough box-and-whisker plot. A non-parametric Kruskall-Wallis test was used to compare the soil data from the vegetable and cereal fields. A Principal Component Analysis was performed for each cropping system on the centered-standardized survey data with CANOCO 5.1 to summarize the variability of the cropping practices across the farms and for all the cropping system to summarize the variability of the cropping practices using the socio-economic conditions of the farmers. The qualitative information was encoded as dummy variables using 1 for the presence and 0 for the absence.

\section{Results}

\subsection{Farms Socio-economic Conditions}

The respondents were mainly male (93.3\%) as shown in the Table 1 . The land occupancy status was dominated by the loan (45\%). About $35 \%$ of the farmers owned the land including the half of the women. The majority of the farmers were illiterate (70\%) and only $9.2 \%$ reached the high school level. About $63 \%$ of the farmers was affiliated to a socio-professional organization. There was a large variability in the age of the farmers and the land 
use duration. In average, the respondents were 39 years old, holding about 0.5 ha of land cropped since 12 years with a labor of 3 workers.

Table 1. Socio-economic conditions of farmers in the peri-urban areas of Ouagadougou, Burkina Faso

\begin{tabular}{lll}
\hline & & Percentage \\
\hline \multirow{3}{*}{ Occupancy status of land } & Renting & 9.2 \\
& Loan & 45.0 \\
& Heritage & 10.8 \\
& Owner & 35.0 \\
Education level & Illiterate & 70.0 \\
& Alphabetized & 10.0 \\
& Elementary school & 10.8 \\
Member of farmers's organization & High school & 9.2 \\
\hline & Yes & 63.3 \\
\hline Age of farmers & No & 36.7 \\
Cropped surface (ha) & & Average \pm SD \\
Land use duration & & $39 \pm 9.8$ \\
Number of working people & & $0.54 \pm 0.3$ \\
\hline
\end{tabular}

\subsection{Cropping Systems}

Table 2 shows that about $15 \%$ of farmers were exclusively vegetable growers while $95 \%$ grew both cereals and vegetables. Whether in exclusive vegetables cultivation or in both cereals and vegetables cultivation, the practice of exclusive polyculture had the low rate. About $38 \%$ of the farms were equipped with animal traction while the rest practiced the operations manually. In exclusive vegetables cultivation, the operations were almost manual.

Table 2. Cropping systems and level of equipment in the peri-urban farms of Ouagadougou, Burkina Faso

\begin{tabular}{llll}
\hline & & \multicolumn{2}{c}{ Percentage per crop type } \\
\cline { 3 - 4 } & & Vegetable & Cereal and Vegetable \\
\hline \multirow{2}{*}{ Cropping systems } & Monoculture & 4.51 & 33.1 \\
& Polyculture & 3.76 & 21.8 \\
& Mono/Polyculture & 6.77 & 30.1 \\
\hline \multirow{2}{*}{ Level of equipment } & Manual & 10.8 & 50.8 \\
& Animal traction & 0.83 & 37.5 \\
\hline
\end{tabular}

\subsection{Fertilization Practices}

For the farms where only vegetables were produced, the rates of organic amendment were in average $0.6,0.5$ and $2 \mathrm{t} \mathrm{ha}^{-1}$ respectively in monoculture, polyculture and mono/polyculture systems (Figure 1). The rates of complex NPK mineral fertilizer were 235, 275 and $600 \mathrm{~kg} \mathrm{ha}^{-1}$ and 157, 114 and $500 \mathrm{~kg} \mathrm{ha}^{-1}$ for urea in monoculture, polyculture and mono/polyculture systems. For the farms where both vegetables and cereals were produced, the rates of organic amendment were in average $0.7,1.3$ and 0.9 tha $^{-1}$ respectively in monoculture, polyculture and mono/polyculture systems (Figure 2). The rates of complex NPK mineral fertilizer were 386, 605 and $530 \mathrm{~kg}$ $\mathrm{ha}^{-1}$ and 201, 301 and $238 \mathrm{~kg} \mathrm{ha}^{-1}$ for urea respectively in monoculture, polyculture and mono/polyculture systems. The highest rates of organic and mineral fertilization were applied by the farmers practicing both polyculture and monoculture in vegetables cropping while in both cereals and vegetables cropping the highest rates of fertilization were applied by the farmers practicing polyculture. 

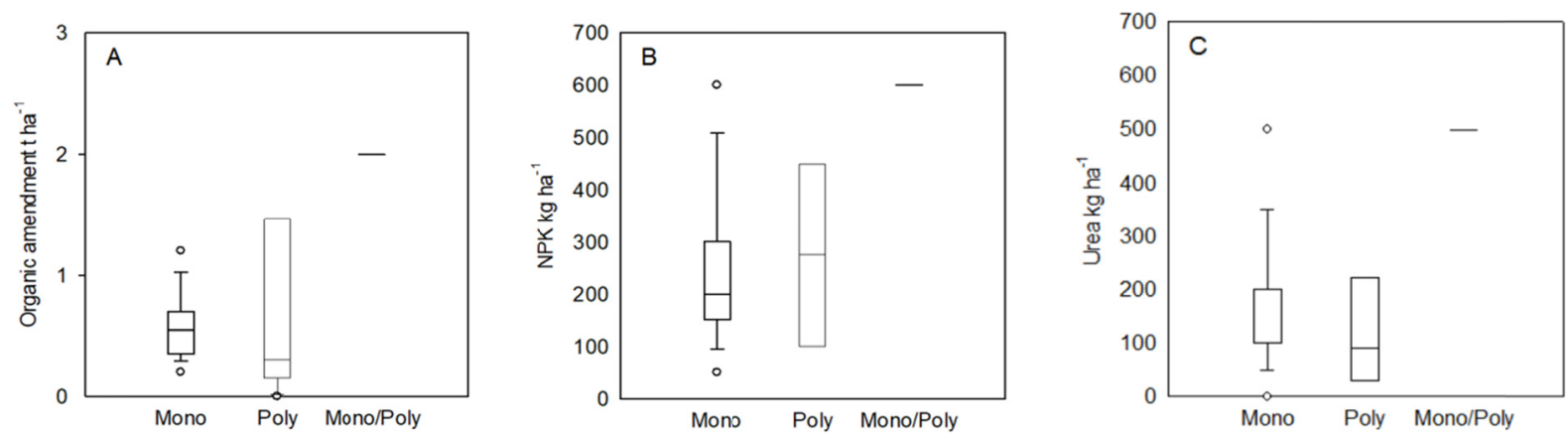

Figure 1. Rate of organic amendment and mineral fertilizers applied by farmers producing only vegetables in different cropping systems in the peri-urban areas of Ouagadougou, Burkina Faso

Note . Mono $=$ monoculture; Poly $=$ polyculture; Mono/poly = practice of monoculture and polyculture); horizontal line in the box-plot indicates the mean and the circles indicate the outliers.
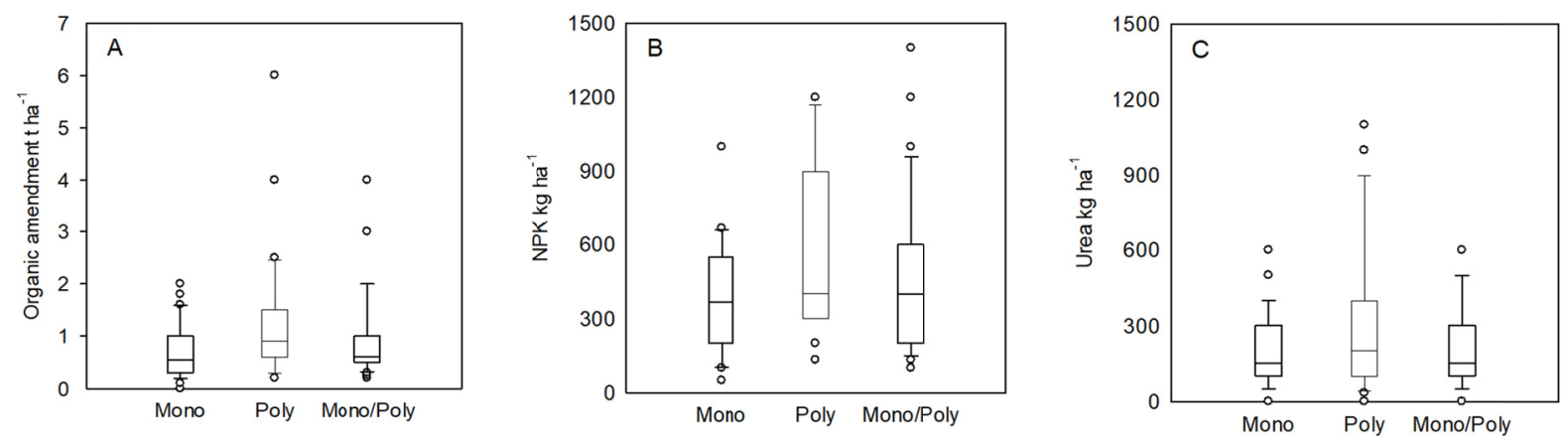

Figure 2. Rate of organic amendment and mineral fertilizers applied by farmers producing both cereal and vegetable in different cropping systems in the peri-urban areas of Ouagadougou, Burkina Faso

Note . Mono $=$ monoculture; Poly $=$ polyculture; Mono/poly $=$ practice of monoculture and polyculture; horizontal line in the box-plot indicates the mean and the circles indicate the outliers.

\subsection{Soil Chemical Properties}

For the farms where only vegetables were produced, there was no significant difference in soil available $\mathrm{P}$ and available $\mathrm{K}$ contents (Table 3). However, soil organic carbon was significantly lower in monoculture than in polyculture. For the farms where both vegetables and cereals were produced, there was no significant differences in soil carbon and available $\mathrm{P}$ contents whereas soil available $\mathrm{K}$ was significantly higher in monoculture than in polyculture.

Table 3. Soil chemical properties according to cropping systems in vegetable and/or cereals fields in the peri-urban areas of Ouagadougou, Burkina Faso

\begin{tabular}{|c|c|c|c|c|}
\hline Cropping systems & Crop type & Carbone & P Bray & Available K \\
\hline & & $\mathrm{g} \mathrm{kg}^{-1}$ & \multicolumn{2}{|c|}{ mg kg${ }^{-1}$} \\
\hline Monoculture & & $5.8 \pm 1.2$ & $18.1 \pm 7.90$ & $153 \pm 43$ \\
\hline Polyculture & Vegetables & $7.5 \pm 1.5$ & $16.1 \pm 10.7$ & $134 \pm 49$ \\
\hline Mono/Polyculture & & $5.0 \pm 0.5$ & $14.2 \pm 1.10$ & $84 \pm 5.6$ \\
\hline Kruskal-Wallis $p$ value & & 0.022 & 0.091 & 0.162 \\
\hline Monoculture & & $8.1 \pm 3.4$ & $13.7 \pm 5.0$ & $171 \pm 65$ \\
\hline Polyculture & Cereals and Vegetables & $8.2 \pm 4.3$ & $14.6 \pm 5.4$ & $115 \pm 29$ \\
\hline Mono/Polyculture & & $6.4 \pm 0.5$ & $18.7 \pm 3.3$ & $163 \pm 19$ \\
\hline Kruskal-Wallis p value & & 0.598 & 0.832 & 0.016 \\
\hline
\end{tabular}




\subsection{Variability of Farms According to Cropping Practices}

\subsubsection{Monoculture System}

For the farms where monoculture was practiced, the cropping practices composed of the rates of fertilization, number of cropped species and cropped land surface explained up to $63 \%$ of the variability. The first axis explained about $36 \%$ of the variability and was mostly correlated with the rates of organic fertilization while the second axis explained about $28 \%$ of the variability and was mostly correlated with the number of cropped vegetable species. The highest rates of fertilization were observed in farms located in Roumtenga and the highest number of cropped species and highest cropped land surface in farms located in Peodogo.

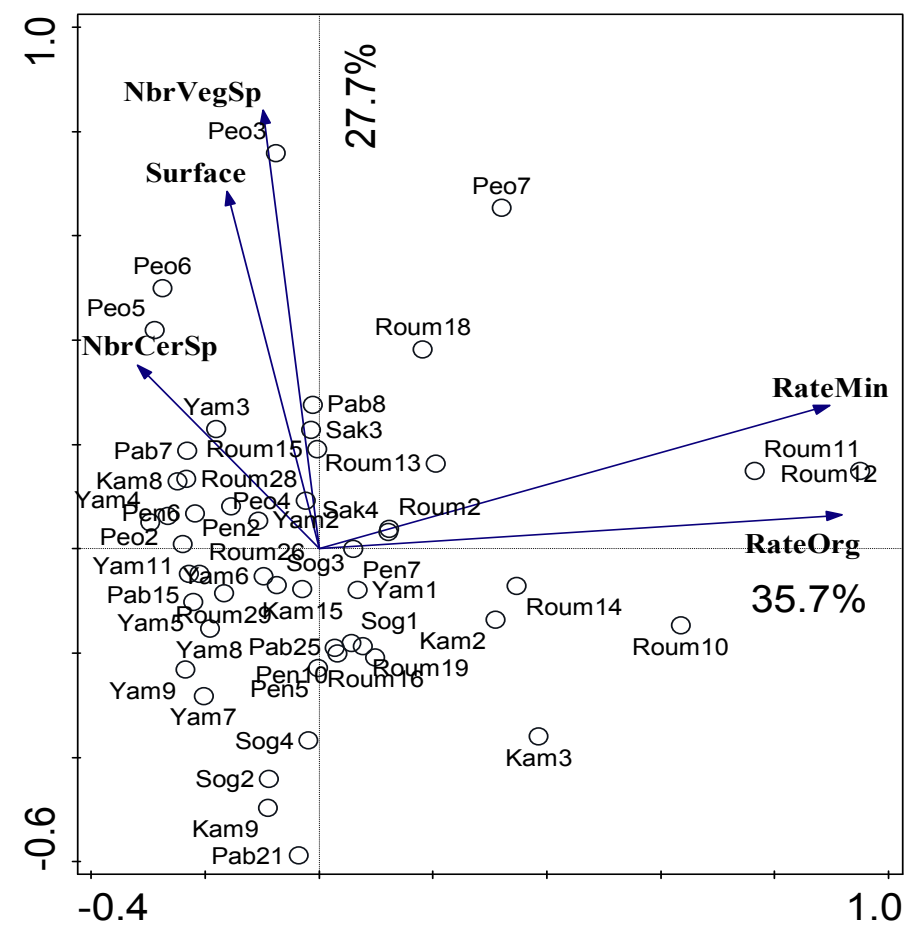

Figure 3. Principal component analysis showing the variability of cropping practices across peri-urban farms practicing monoculture in Ouagadougou, Burkina Faso

Note. Arrows indicate the cropping practies; circles indicates the farmers plots indicated by the site names abbreviated; practices are: NbrVeg : number of cereal species; NbrVegSp: number of vegetable species; RateMin: rate of mineral fertilization; RateOrg: rate of organic fertilization; Surface: cropped surface; $\mathrm{N}=50$ (population size).

\subsubsection{Polyculture System}

For the farms where polyculture was practiced, the cropping practices composed of the rates of fertilization, number of cropped species and cropped land surface explained up to $64 \%$ of the variability. The first axis explained about $33 \%$ of the variability and was mostly correlated with the number of cereal species. The second axis explained about $31 \%$ of the variability and was mostly correlated mostly with the cropped land surface. The highest rates of fertilization were observed in farms located in Pabré, Roumtenga, Sakoula and the highest cropped land surface in farms located in Kamboinsé, Loumbila, Pabré, Peodogo and Roumtenga. 


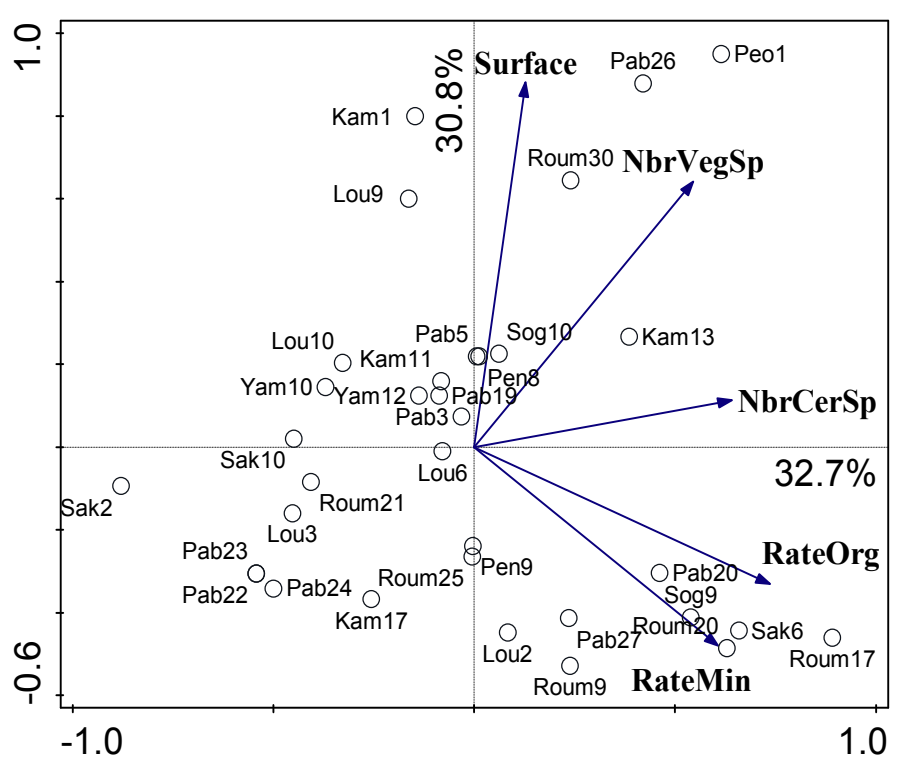

Figure 4. Principal component analysis showing the variability of cropping practices across peri-urban farms practicing Polyculture in Ouagadougou, Burkina Faso

Note. Arrows indicate the cropping practies; circles indicates the farmers plots indicated by the site names abbreviated; practices are: NbrVeg : number of cereal species; NbrVegSp: number of vegetable species; RateMin: rate of mineral fertilization; RateOrg: rate of organic fertilization; Surface: cropped surface; $\mathrm{N}=34$ (population size).

\subsubsection{Mono/Polyculture Systems}

For the farms where both monoculture and polyculture were practiced, the cropping practices composed of the rates of fertilization, number of cropped species and cropped land surface explained up to $60 \%$ of the variability. The first axis explained about $39 \%$ of the variability and was mostly correlated with the rates of organic. The second axis explained about $21 \%$ of the variability and was correlated with the number of cereal species. The highest rates of fertilization were observed in farms located in Pabré and the highest cropped land surface in farms located in Loumbila, Sakoula, Kamboinsé. The farms with the highest cropped surface had the lowest number of vegetable species. 


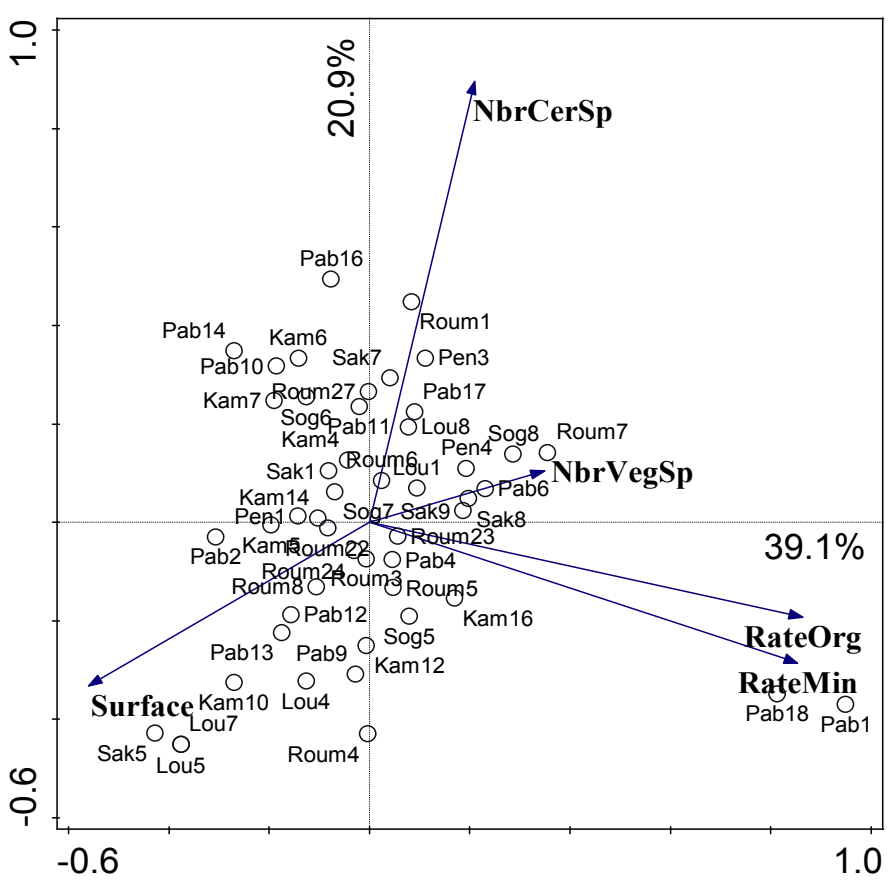

Figure 5. Principal component analysis showing the variability of cropping practices across peri-urban farms practicing Mono/Polyculture in Ouagadougou, Burkina Faso

Note. Arrows indicate the cropping practies; circles indicates the farmers plots indicated by the site names abbreviated; practices are: NbrVeg : number of cereal species; NbrVegSp: number of vegetable species; RateMin: rate of mineral fertilization; RateOrg: rate of organic fertilization; Surface: cropped surface; $N=49$ (populaion size).

\subsubsection{Influence of Farmers Socio-economic Conditions on the Cropping Practices}

The farmer's socio-economic conditions composed of the farmer age, gender, farm age, the education level, the level of equipment, number of workers and land tenure explained up to $59 \%$ of the variability in the cropping practices. The first axis explained about $33 \%$ of the variability and was slightly determined by the land tenure and the education level. The land tenure was correlated with the rate of mineral and organic fertilizations. The second axis explaining about $26 \%$ of the variability was mostly determined by the number of workers which was correlated with the number of vegetable species. The oldest farms were the largest and were hold by the oldest farmers. 


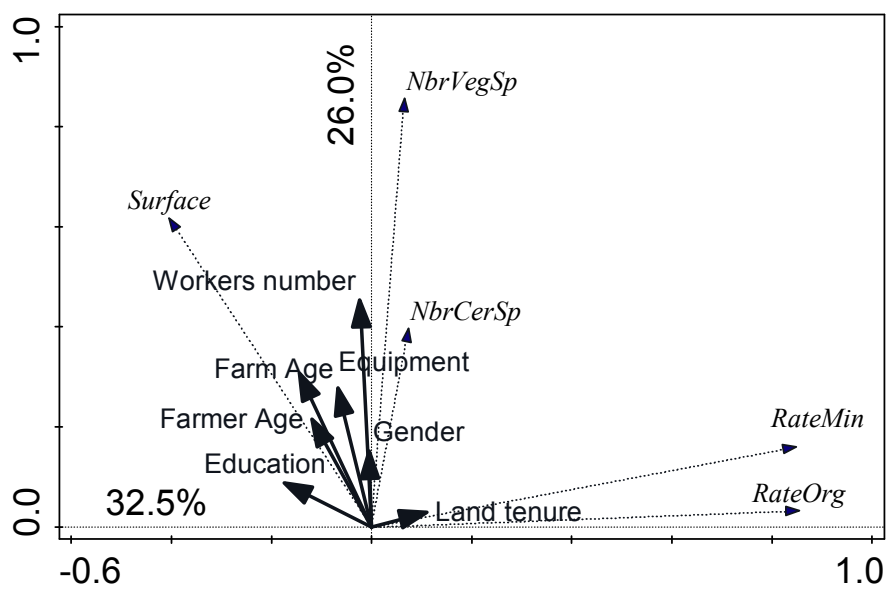

Figure 6. Principal component analysis summarizing the variability of farmers practives according to their socio-economic conditions in peri-urban areas of Ouagadougou, Burkina Faso

Note. Arrows indicate the socio economic conditions while the dotted arrow indicate the practices; practices are: NbrVeg: number of cereal species; NbrVegSp: number of vegetable species; RateMin: rate of mineral fertilization; RateOrg: rate of organic fetrilization; Surface: cropped surface; $N=133$ (population size).

\section{Discussion}

\subsection{Farms Socio-economic Conditions and Cropping Systems}

Agriculture in our studied peri urban areas is mainly practiced by men. This is in accordance with Abdulkadir et al. (2011) who found 5 to 19\% female headed urban farms in Sikasso (Mali) and Bobo-Dioulasso (Burkina Faso) and none in Kano (Nigeria). In Burkina Faso, women are mostly active in the maket aspect of the value chain of the peri urban agriculture and to some extent in the production in urban areas. The women met in production are very often widows or very poor and unmarried women who organize themselves into associations. The fact that only few farmers are land owner highlitht some incertancies and land insecurity in urban and peri-urbam agriculture which is an often case in african countries as indicated in Cissé et al. (2005). This land insecurity may lead to a low investment in soil fertility management as observed by Ouédraogo et al. (2019) in the urban farms located in the green belt of Ouagadougou in Burkina Faso, where fertilization was mostly practiced by land owners. It was not surprising to see a very low education level within the respondents in our study. Indeed, urban and peri urban agriculture in Africa is like an escape for those who have not succeeded in school and who are looking for a way to survive. It was interesting to see that most of the farmers belong to a socio-profesionnal organization which is somehow a way for them to get fundings (Kiba et al., 2012a) and also mutually share knowedge regarding soil and crop managements and market opportunities.

The low proportion of farmers practicing exclusively vegetable production is explained by the fact that our study sites are mostly located in peri-urban areas where cereals cropping is mostly practiced (Kiba et al., 2012b). The exclusive vegetables cropping is mostly practiced within the cities in order to provide fresh products to the city dwellers. Our results showed that there was no more decisive cultivation system on the peri-urban farms. Farmers practice monoculture, polyculture or both depending on their needs for consumption or sales. Dossa et al. (2011) showed that most of the urban and peri-urban farms in Burkina Faso, Mali and Nigeria are market-oriented. Apart from some cereal production farms, production in urban and peri-urban areas is carried out manually without mechanized ploughing tools, which explains the low level of equipment that we observed. This low level of equipment is also explained by the small size of the farms $(0.5 \pm 0.3 \mathrm{ha})$.

\subsection{Fertilization Practices and Soil Properties}

The nutrients inputs through organic and mineral fertilizers in our peri-urban farms are lower than in the urban farms studied by Kiba et al. (2012a) in Ouagadougou and Lompo et al. (2012) in Bobo-Dioulasso the two main cities of Burkina Faso. The proximity of the urban farms to organic ressources produced in the cities as solid wastes, the easy access to mineral fertilizers due to the proximity of markets and the fact that urban farms are strongly market-oriented explain these differences. The vegetables are more maket-oriented crops than the cereals explaining why the farmers invest more in the fertilization of the vegetables than the cereals fields. 
The lowest soil organic carbon in the monoculture system in exclusive vegetable production is explained by the lowest organic inputs in this system. The lowest soil available $\mathrm{K}$ in the polyculture system in the both cereals and vegetables cropping is likely due to a higher $\mathrm{K}$ uptake in the polyculture compared to the monoculture due to a complementary in crop roots architecture (Postma et al., 2012).

\subsection{Farms Variability as Affected by Cropping Systems and Cropping Practices}

The monoculture is mostly driven by vegetables cropping while the polyculture by cereals cropping as highlited by the principal component analyses. Indeed in West Africa, intercropping of cereals and vegetables is a common pratice (Tignegre et al., 2018), the cereals being the main crops. In this system, the vegetables are in most cases grown by women for maket and/or to provide food to the familly while the cereal is the property of the men. In the monoculture on the other hand, the target crops are vegetables so as to maximise the profit as those crop have a high market value and some have different croping cycles and they require various management which may not allow an intercropping. Our results showed that the available land surface is an important factor determing the number of cropped species in all the cropping systems. Indeed farmers focus on a limited number of species when the land surface is limited so as to maximise the profit for those species. As shown in Kiba et al. (2012a) in urban farming in Ouagadougou, the sites identities influence the cropping practices such as the rates of fertilization because of differences in access to organic resources and mineral fertilizers. Our results also showed that land availability and cropped species are site and also farm dependant. The sites of Pabré and Salkoula were recently integrated as part of the city of Ouagadougou due to their proximity explaining the high inputs of fertilizers in those areas.

\subsection{Cropping Practices as Affected by Farms Socio-economic Conditions}

The studied farms socio-economic conditions composed of the farmer age, gender, farm age, the education level, the level of equipment, number of workers determine more the number of cropped species and the cropped surface than the fertilization practices which are mostly determined by the land occupancy status as shown in previous studies (Adjei-Nsiah, 2019; Ouédraogo et al., 2019). The fact that the oldest farms have the highest surfaces highlight the issue of land availability over time. Indeed, most of the oldest farms belong to the land owners and therefore have more surface than the recent farms which are obtained via renting or loans in more often for small surfaces.

\section{Conclusion}

The cropping practices explained up to $60 \%$ of the variability of the farms whether monoculture, polyculture or both were practiced. The nutrients inputs through organic and mineral fertilizers in our peri-urban farms were lower than reported for urban farms. Soil organic carbon was significantly lower in monoculture than in polyculture due to differences in the rates of organic inputs while for available $\mathrm{K}$ the contrary was observed suggesting a higher $\mathrm{K}$ uptake in the polyculture. Cropping practices were determined by farms socio-economic conditions. The farmer's socio-economic conditions composed of the farmer age, gender, farm age, the education level, the level of equipment, number of workers and land tenure explained up to $59 \%$ of the variability in the cropping practices. The peri-urban agriculture if well managed can feed the increasing population of the cities. However, this require to i) identify and dedicate areas for this activities, ii) increase farmer's knowledge on soil fertility management through trainings ii) evaluate the needs for consumption and the market opportunities of the products so as to allocate cropped surfaces accordingly and finally encourage the youth to engage themselves as agro businessmen in this sector.

\section{Acknowledgements}

We are grateful to the farmers of all the studied sites for the good collaboration and the students for the data collection.

\section{References}

Abdulkadir, A., Dossa, L. H., Lompo, D. J.-P., Abdu, N., \& van Keulen, H. (2012). Characterization of urban and peri-urban agroecosystems in three West African cities. International Journal of Agricultural Sustainability, 10(4), 289-314. https://doi.org/10.1080/14735903.2012.663559

Adjei-Nsiah, S. (2019). Integrated Soil Fertility Management Options for Sustainable Intensification in Maize-Based Farming Systems in Ghana. In D. Panpatte \& Y. Jhala (Eds.), Soil Fertility Management for Sustainable Development (pp. 291-303). Springer, Singapore. https://doi.org/10.1007/978-981-135904-0_14 
Amoah, P., Drechsel, P., Abaidoo, R. C., \& Ntow, W. J. (2006). Pesticide and pathogen contamination of vegetables in Ghana's urban markets. Archives of Environmental Contamination and Toxicology, 50(1), 1-6. https://doi.org/10.1007/s00244-004-0054-8

Bray, R. H., \& Kurtz, L. T. (1945). Determination of total organic and available forms of Phosphorus in soils. Soil Science, 59(1), 39-45. https://doi.org/10.1097/00010694-194501000-00006

Chagomoka, T., Drescher, A., Glaser, R., Marschner, B., Schlesinger, J., \& Nyandoro, G. (2015). Contribution of urban and periurban agriculture to household food and nutrition security along the urban-rural continuum in Ouagadougou, Burkina Faso. Renewable Agriculture and Food Systems, 32(1), 5-20. https://doi.org/ $10.1017 / \mathrm{S} 1742170515000484$

Cissé, O., Diop, N. F. G., \& Sy, M. (2005). Institutional and legal aspects of urban agriculture in French speaking West Africa: from marginalization to legitimization. Environment\&Urbanization, 17(1), 143-154. https://doi.org/10.1177/095624780501700211

Dossa, L. H., Abdulkadir, A., Amadou, H., Sangare, S., \& Schlecht, E. (2011). Exploring the diversity of urban and peri-urban agricultural systems in Sudano-Sahelian West Africa: An attempt towards a regional typology. Landscape and Urban Planning, 102(3), 197-206. https://doi.org/10.1016/j.landurbplan.2011. 04.005

Drechsel, P., \& Dongus, S. (2010). Dynamics and sustainability of urban agriculture: Examples from sub-Saharan Africa. Sustainable Science, 5(1), 69-78. https://doi.org/10.1007/s11625-009-0097-x

Drechsel, P., Graefe, S., Sonou, M., \& Cofie, O. O. (2006). Informal irrigation in urban West Africa: An overview (p. 40, IWMI Research Report 102). International Water Management Institute, Colombo.

Fontès, J., \& Guinko, S. (1995). Carte de la végétation et de l'occupation du sol du Burkina Faso (p. 66). Institut de la Carte International de la Végétation, Université Toulouse France; Institut du Développement Rural, Université Ouagadougou, Burkina Faso.

Kiba, D. I., Zongo, N. A, Lompo, F., Jansa, J., Compaore, E., Sedogo, P. M., \& Frossard, E. (2012a). The diversity of fertilization practices affects soil and crop quality in urban vegetable sites of Burkina Faso. European Journal of Agronomy, 38, 12-21. https://doi.org/10.1016/j.eja.2011.11.012

Kiba, D. I., Lompo, F., Compaore, E., Randriamanantsoa, L., Sedogo, P. M., \& Frossard, E. (2012b). A decade of non-sorted solid urban wastes inputs safely increases sorghum yield in peri-urban areas of Burkina Faso. Acta Agriculturae Scandinavica, Section B-Soil \& Plant Science, 62(1), 59-69. https://doi.org/10.1080/ 09064710.2011 .573802

Lompo, D. J.-P., Sangaré, S. A. K., Compaoré, E., Sedogo, P. M., Predotova, M., Schlecht, E., \& Buerkert, A. (2012). Gaseous emissions of nitrogen and carbon from urban vegetable gardens in Bobo-Dioulasso, Burkina Faso. Journal of Plant Nutrition and Soil Science, 175(6), 846-853. https://doi.org/10.1002/ jpln.201200012

Mougeot, L. J. A. (2000). Urban agriculture: Definition, presence, potentials and risks. In N. Bakker, M. Dubbeling, S. Gundel, U. Sabel-Koschella, \& H. de Zeeuw (Eds.), Growing cities, growing food: Urban agriculture on the policy agenda (pp. 1-42). Deutsche Stiftung fur Internationale Entwicklung (DSE), Zentralstelle fur Ernahrung und Landwirtschaft, Feldafing.

Naré, R. W. A., Savadogo, P. W., Gnankambary, Z., Nacro, H. B., \& Sedogo, P. M. (2015). Analyzing Risks Related to the Use of Pesticides in Vegetable Gardens in Burkina Faso. Agriculture, Forestry and Fisheries, 4(4), 165-172. https://doi.org/10.11648/j.aff.20150404.13

Orsini, F., Kahane, R., Nono-Womdim, R., \& Gianquinto, G. (2013). Urban agriculture in the developing world: A review. Agronomy and Sustainable Development, 33(4), 695-720. https://doi.org/10.1007/s13593013-0143-z

Ouédraogo, D. B., Belem, B., Kiba, D. I., Gnankambary, Z., Nacro, H. B., \& Sedogo, P. M. (2019). Analyzing Constraints and Opportunities of Urban Agriculture in the Greenbelt of Ouagadougou, Burkina Faso. Agriculture, Forestry and Fisheries, 8(3), 73-80. https://doi.org/10.11648/j.aff.20190803.13

Pallo, F. J. P., \& Thiombiano, L. (1989). Les sols ferrugineux tropicaux lessivés à concrétions du Burkina Faso: caractéristiques et contraintes pour l'utilisation agricole. In Soltrop 89 (Eds.), Actes du premier séminaire franco-africain de pédologie tropicale, Lomé, 6-12 février 1989 (pp. 307-327). Paris: ORSTOM; Lomé, Togo. 
Postma, J. A., \& Lynch, J. P. (2012). Complementarity in root architecture for nutrient uptake in ancient maize/bean and maize/bean/squash polycultures. Annals of Botany, 110(2), 521-534. https://doi.org/ 10.1093/aob/mcs082

Sangaré, S. K., Compaoré, E., Buerkert, A., Vanclooster, M., Sedogo, P. M., \& Bielders, L. C. (2012). Field-scale analysis of water and nutrient use efficiency for vegetable production in a West African urban agricultural system. Nutrient Cycling in Agroecosystem, 92(2), 207-224. https://doi.org/10.1007/s10705-012-9484-2

Tignegre, J. B. S., Larbi, A., Tenkouano, A., Nurudeen, A., Asante, M., Boateng, R., ... Chagomoka, T. (2018). Optimization of Maize-Vegetable (African Eggplant and Pepper) Intercrops in Northern, Upper West and Upper East Regions of Ghana. JOJ Horticulture and Arboriculture, 1(2), 555-557.

Walkley, A., \& Black, J. A. (1934). An examination of the Detjareff method for determining soil organic matter and a proposed modification of the chromatic acid titration method. Soil Science, 37(1), 29-38. https://doi.org/10.1097/00010694-193401000-00003

\section{Copyrights}

Copyright for this article is retained by the author(s), with first publication rights granted to the journal.

This is an open-access article distributed under the terms and conditions of the Creative Commons Attribution license (http://creativecommons.org/licenses/by/4.0/). 